\begin{tabular}{|l|l|}
\hline $\begin{array}{l}\text { APIC Analisa Pemikiran Insan Cendikia } \\
\text { Volume IV, No. } 1 \text { (2021) 52-58 }\end{array}$ & ISSN: 2654-7201 \\
e-ISSN: 0000-0000 \\
\hline
\end{tabular}

\title{
SUPERVISI AKADEMIK SEBAGAI UPAYA UNTUK MENINGKATKAN KINERJA GURU PENDIDIKAN AGAMA ISLAM DAN BUDI PEKERTI (PAIBP) SEKOLAH DASAR DI KOTA BINJAI
}

\author{
Ikhsanti Hannum ${ }^{1}$ \\ ${ }^{1}$ Kantor Kementerian Agama Kota Binjai
}

\begin{abstract}
Balai Diklat Keagamaan Medan Jl. TB. Simatupang No. 122 Medan Telp. (061)8456256 E-mail Penulis: ikhsantipengawas@gmail.com Naskah diterima: 11 April 2021 Naskah Direvisi: 12-20 April 2021

Naskah disetujui: 30 April 2021 Website Journal: http://apicbdkmedan.kemenag.go.id
\end{abstract}

\begin{abstract}
ABSTRAK
Tulisan ini mendeskripsikan tentang peningkatan kinerja guru dalam melaksanakan proses pembelajaran, setelah dilakukannya supervisi akademik. Perubahan dalam wujud kehadiran, pemenuhan perangkat kerja, kedisiplinan waktu, penggunaan media, dan kemampuan mengajar, menjadi ke arah yang lebih baik menjadi indikatornya. Metode yang digunakan untuk penelitian adalah kualitatif dengan teknik pengumpulan dan penganalisisan data kuantitatif, dan pendekatan Penelitian Tindakan Kelas. Guru yang digunakan sebagai sampel berjumlah 20 orang, dan hasil yang didapat menunjukkan bahwa setelah dilaksanakan penelitian pada siklus I dan siklus II, sebanyak 85\% sampel untuk 10 aspek penilaian meningkat kinerjanya. Data tersebut menunjukkan adanya pencapaian keberhasilan pengimplementasian supervisi akademik pengawas terhadap guru PAIBP.
\end{abstract}

Kata Kunci: PAIBP, Pengawasan, Peningkatan Kinerja, Supervisi Akademik

\begin{abstract}
This paper describes enhancement in teacher performance in implementing the learning process, after academic supervision is carried out. Transformation in the form of attendance, fulfillment of work tools, time discipline, use of media, and teaching skills are indicators of this. The method used for research is qualitative with quantitative data collection and analysis techniques, and Classroom Action Research approach. The number of teachers used as a sample was 20 people, and the results obtained showed that after the research was carried out in cycle I and cycle II, a total of $85 \%$ sampled for 10 aspects of the assessment increased their performance. This data shows the achievement of the successful implementation of supervisory academic supervision of PAIBP teachers.
\end{abstract}

Keywords: Academic Supervision, PAIBP, Performance Enhancement, Supervision.

\section{PENDAHULUAN}

Guru merupakan salah satu komponen penting di suatu lembaga pendidikan, dikarenakan guru merupakan orang yang dianggap mampu menjembatani pentransferan ilmu ke siswa. Dengan kata lain, guru merupakan orang yang paling penting kedudukannya dalam suatu proses pembelajaran dan pendidikan yang dilakukan, karena keberhasilan suatu proses belajar tersebut ditentukan oleh keberadaan seorang guru. Kemampuan dan motivasi seorang guru dalam menurunkan ilmu ke siswa juga menjadi hal penting untuk dikuasai secara maksimal, sehingga segala kendala yang terjadi dalam proses pembelajaran yang dilakukan dapat teratasi dengan baik.

Sebagai seorang manusia, guru juga selalu dihadapkan pada kondisi dan situasi yang tidak stabil. Hal tersebut bisa menyebabkan guru memiliki kondisi yang juga berbeda, sehingga terjadi ketidak stabilan fisik dan psikisnya. Salah contoh nyata adalah pendemi covid-19, yang menyebabkan sekolah 
melakukan pembelajaran dengan tidak tatap muka langsung (daring atau luring), dan pada akhirnya guru malas masuk untuk mengajar.

Berdasarkan hasil observasi peneliti terhadap guru Pendidikan Agama Islam dan Budi Pekerti (PAIBP) yang termasuk ke dalam binaan, dengan adanya pelaksanaan pembelajaran secara online, $70 \%$ guru menjadi terkesan kurang semangat untuk mengajar dan juga berkurang kinerjanya. Kondisi tersebut terlihat dari kurang aktifnya mereka masuk ke kelas dengan menggunakan media pembelajaran online, tidak hadir ke sekolah, atau hadir dan hanya duduk bercerita dengan teman-teman guru lainnya, yang masih ditambah dengan tidak melengkapinya dengan perangkat pembelajaran, tidak disiplin waktu, dan kurang memanfaatkan media pembelajaran yang lebih interaktif. Masalah tersebut ditemui manakala peneliti (yang juga sebagai seorang pengawas guru PAIBP) datang ke sekolah, dan juga hasil dari bertanya kepada beberapa orang siswa secara acak. Hal ini tentunya merupakan keadaan yang kurang baik bagi berlangsungnya proses pembelajaran dan pendidikan di sekolah.

Dari hasil temuan tersebut, peneliti beranggapan bahwa guru-guru binaan peneliti telah mengalami penuruan kinerja. Oleh karena itu, peneliti beranggapan perlunya memperbaiki keadaaan tersebut dan mencoba untuk meningkatkan kembali kinerja mereka, melalui supervisi akademik.

Supervisi akademik merupakan rangkaian kegiatan yang digunakan untuk membantu dan mengembangkan kemampuan guru dalam mengelola pembelajaran yang dilakukan dengan maksud utama mencapai tujuan pembelajaran yang sudah ditetapkan (Glickman, dkk, 2007). Melihat pengertiannya, bisa dipahami bahwa supervis akademik merupakan kegiatan yang berkaitan dengan pengawas sekolah/ madrasah dengan guru yang dibinanya. Hal ini berkaitan dengan tujuan dari supervisi akademik itu dilakukan, yaitu untuk membantu guru mengembangkan kompetensi, kurikulum, dan kelompok kerja, serta melakukan bimbingan untuk penelitian (Sergiovanni, dalam Susanti, 2019:86). Menurut Dodd (ibid:88), prinsip-prinsip dari supervisi akademik memuat beberapa criteria, diantaranya praktis, sistematis, objektif, realistis, antisipatif, konstruktif, kooperatif, kekeluargaan, demokratis, aktif, humanis, berkesinambungan, terpadu dan komprehensif. Sedangkan teknik yang digunakan ada yaitu individu seperti kunjungan kelas, observasi kelas, kunjungan individual, kunjungan antar kelas dan kelompok seperti kepanitiaan, kerja kelompok, laboratorium dan kurikulum, membaca terpimpin, pertemuan guru, lokakarya, dan lain-lain. (Gwynn, dalam Wakingah, 2018:349). Namun begitu, untuk melakukan teknik kelompok ini harus mempertimbangkan beberapa faktor kepribadian guru seperti minat, bakat, temperamen kebutuhan, somatik dan sifat guru. (Lucio dan Mc Neill, dalam Maralih, 2014:185).

$$
\text { Yamin dan Maisah (2010:31) }
$$

mengatakan bahwa kinerja guru merupakan perilaku atau respon yang dikerjakan ketika mereka menghadapi tugas, menyangkut semua kegiatan atau tingkah laku yang dialami tenaga pengajar, jawaban yang dibuat, dengan maksud untuk memberikan hasil atau tujuannya. Dijelaskan lagi, bahwa kinerja guru merupakan penampakan kompetensi yang dimiliki oleh guru, berupa kemampuannya dalam melaksanakan tugas-tugas dan kewajiban secara layak dan bertanggungjawab. Pendapat tersebut didukung oleh Uno dan Nina (2014:60) yang mengatakan bahwasanya kinerja yang nyata akan mampu melewati dari apa yang telah di standarkan dalam kinerjanya sendiri, atau dengan kata lain menetapkan standar tertinggi bagi dirinya sendiri, sehingga mampu melewati batas-batas yang telah ditentukan oleh orang lain. Dikutip dari Permediknas no. 41 tahun 2007 halaman 2, dikatakan bahwa kinerja guru adalah prestasi mengajar yang dihasilkan dari aktifitas yang 
dilakukan oleh guru dalam tugas pokok dan fungsinya secara realisasi konkrit dalam dan merupakan konsekuensi logis sebagai tenaga professional bidang pendidikan. Beberapa pengertian di atas jelas mengatakan bahwa kinerja guru pada intinya adalah kemampuan guru dalam memenuhi dan meningkatkan tuntutan kerja yang telah ditetapkan, hingga mencapai batas kemampuan tertinggi sesuai dengan kemampuan dan kebutuhan.

Kurikulum 2013 menjadi kurikulum terakhir yang digunakan pada sistem pendidikan di Indonesia pada saat ini. Kurikulum ini merupakan pengembangan dari Kurikulum Tingkat Satuan Pendidikan (KTSP) yang diberlakukan mulai tahun 2006, dengan penambahan (suplemen) unsur karakter pada tahun 2009. Pemunculan kurikulum 2013 ini dilandasi oleh pemikiran tentang tantangan masa depan, persepsi masyarakat, perkembangan pengetahuan dan pedagogi, kompetensi masa depan, dan fenomena negative yang mengemuka (Pedoman Pelatihan Implementasi Kurikulum 2013, 2013:4). Peinjelasan tersebut dipertegas oleh Mulyasa (2013:163) yang mengatakan bahwa kurikulum 2013 berbasis karakter dan kompetensi, karena tidak hanya menekankan kepada penguasaan kompetensi siswa, tetapi juga terhadap pembentukan karakter. Proses pembentukan karakter tersebut dimuat dalam Kompetensi Inti (KI) 1 hingga 4, yang mana KI 1 dan 2 menerapkan penguasaan karakter akhlak religius dan sikap, sedangkan KI 3 dan 4 merupakan penerapan penguasaan pada karakter kemampuan teoritis dan praktis siswa. Seperti diketahui, bahwa Kurikulum 2013 ini diterapkan pada jenjang pendidikan dasar (SD/MI dan SMP/ MTs) dan pendidikan menengah (SMA, SMK, MA).

Pendidikan Agama Islam dan Budi Pekerti merupakan salah satu mata pelajaran yang wajib diajarkan pada penerapan K13 di tingkat Sekolah Dasar (SD) atau Madrasah Ibtidaiyah (MI). Pendidikan Agama Islam dan Budi Pekerti merupakan salah satu mata pelajaran ada di Kurikulum 2013, berdasarkan Permendikbud no. 21 Tahun 2016. Perubahan nama tersebut dimulai sejak penerapan KTSP pada tahun 2006, yang muatan isinya mencakup tentang aqidah, akhlak, ibadah, dan muamalah untuk pelajaran Agama Islam, dan nilai-nilai kejujuran, kesopanan, disiplin, tanggung jawab dan lain-lain sebagai pelajaran budi pekertinya (karakter). Dari sini terlihat bahwa pemerintah menaruh ekspetasi yang sangat besar terhadap keberadaan mata pelajaran ini, untuk menciptakan manusia yang memiliki jiwa religius dan sikap yang tinggi.

Dari uraian di atas, peneliti membuat hipotesis yaitu apabila supervisi akademik diterapkan maka akan dapat meningkatkan motivasi kerja guru PAIBP tingkat Sekolah Dasar di Kota Binjai.

\section{METODOLOGI PENELITIAN}

Untuk menyelesaikan penelitian ini, peneliti menggunakan jenis penelitian deskriptif yang bersifat kuantitatif, dengan pendekatan Penelitian Tindakan. Objek yang dijadikan sampel adalah guru-guru PAIBP binaan peneliti, dengan jumlah sebanyak 20 orang, yang berasal dari 20 Sekolah Dasar SeKecamatan Binjai Barat dan Binjai Kota di Kota Binjai. Pembatasan jumlah sampel dilakukan dengan alasan guru binaan peneliti berada di sekolah yang terpisah jauh, dan tidak memiliki keluangan waktu yang persis sama, sehingga peneliti hanya meneliti guru-guru yang dekat dan memiliki waktu yang bisa untuk berkumpul, untuk disupervisi. Jumlah tersebut dianggap dapat mewakili keseluruhan jumlah guru binaan. Penelitian ini sendiri dilakukan pada semester ganjil Tahun Pelajaran 2020-2021, selama 8 (delapan) pekan dari bulan Agustus hingga bulan Oktober tahun 2020. Sedangkan penelitian dilakukan dengan menggunakan langkah-langkah yang umum pada penelitian tindakan kelas, yaitu : (1) perencanaan; (2) pelaksanaan; (3) pengamatan; dan (4) refleksi; (Arikunto dkk, 2009:74) 
Data berasal dari beberapa sumber. Asumsi ini diperkuat oleh Moleong (2002) yang mengungkapkan bahwasanya data untuk suatu penelitian bisa didapatkan dari berbagai sumber, seperti misalnya kata-kata dan tindakan dari guru, rekan sejawat, siswa; dan juga dokumen ataupun arsip-arsip. Data-data yang diperlukan didapatkan melalui teknik pengamatan, wawancara, dan kerja laboratorium.

\begin{tabular}{|c|c|c|c|c|c|c|}
\hline \multirow{2}{*}{ No } & \multirow{2}{*}{ Aspek Penilaian } & \multicolumn{5}{|c|}{ Kategori } \\
\hline & & $\mathrm{S}$ & $\mathrm{B}$ & $\mathrm{C}$ & $\mathrm{K}$ & $\mathrm{T}$ \\
\hline 1 & Menguasai bahan ajar yang akan diajarkan & & & & & \\
\hline 2 & Mengelola program belajar mengajar & & & & & \\
\hline 3 & Mengelola kelas & & & & & \\
\hline 4 & Menggunakan media/ sumber belajar & & & & & \\
\hline 5 & Menguasai landasan-landasan kependidikan & & & & & \\
\hline 6 & Mengelola interaksi belajar mengajar & & & & & \\
\hline 7 & Menilai prestasi siswa & & & & & \\
\hline 8 & $\begin{array}{l}\text { Mengenal fungsi dan program bimbingan dan } \\
\text { penyuluhan }\end{array}$ & & & & & \\
\hline 9 & $\begin{array}{l}\text { Mengenal dan menyelenggarakan administrasi } \\
\text { sekolah }\end{array}$ & & & & & \\
\hline 10 & $\begin{array}{l}\text { Memahami prinsip-prinsip dan menafsirkan hasil- } \\
\text { hasil penelitian }\end{array}$ & & & & & \\
\hline & Jumlah & & & & & \\
\hline & Persentase $(\%)$ & & & & & \\
\hline
\end{tabular}

Untuk menganalisis data penelitian, digunakan teknik kuantitatif dengan menggunakan tabel yang berisikan kriteria penilaian. Adapun kriteria yang digunakan untuk melihat peningkatan kinerja guru, diambil dari indikator kinerja yang dikemukakan oleh Sudjana dkk (2004:107), dan memasukkannya ke dalam format penilaian berbentuk tabel sebagai berikut:

\section{Tabel 1. Kriteria dan skor penilaian peningkatan kinerja guru dengan supervisi akademik}

Keterangan :

$\mathrm{S}=$ Sangat Baik

B $\quad$ Baik

$\mathrm{C} \quad$ = Cukup

$\mathrm{K}=$ Kurang

$\mathrm{T} \quad=$ Tidak Baik

Dari tabel penilaian yang digunakan untuk penilaian indicator kinerja tersebut, akan dapat terlihat kondisi guru sebelum dan setelah dilakukannya supervisi akademik.

Pada tulisan ini, peneliti menetapkan batas ketuntasan penelitian sebesar $85 \%$ sampel, yaitu sebanyak 1 orang. Asumsi peneliti adalah jumlah tersebut dapat mewakili jumlah keseluruhan guru binaan peneliti, yang memperoleh nilai dengan kategori minimal Baik. Persentase ketuntasannya digunakan rumus :

Ketuntasan $=\frac{\text { Jumlah persentase }}{\text { Jumlah sampel } x \text { krtiteria }} \times 100$

Dengan asumsi sebesar 85\%, maka total jumlah dari sampel yang harus memenuhi semua aspek minimal dengan kategori Baik total sebanyak 170 orang untuk 10 kategori.

\section{HASIL DAN PEMBAHASAN}

Langkah awal dari penelitian ini adalah mengumpulkan 20 orang guru yang telah diundang sebelumnya, untuk kemudian 
diberitahukan tujuan mereka dikumpulkan. Langkah ini merupakan bentuk pra siklus, dengan tujuan penulis dapat mengetahui seberapa banyak para guru memenuhi indikator dari kinerja yang telah peneliti tentukan. Seperti telah dikemukakan, pada tahap observasi awal peneliti telah menemukan $70 \%$ guru diketahui berkurang kinerjanya, dan ini terbukti dengan hampir semua sampel tidak sampai memenuhi setengah dari kriteria indikator kinerja, sehingga hal ini menjadi landasan peneliti untuk melakukan penelitian tindakan dalam rangka meningkatkan kinerja guru. Hasil wawancara pun menunjukkan bahwa para sampel kurang termotivasi untuk bekerja dan memenuhi segala kriteria, dengan alasan pembelajaran tidak dilakukan dengan tatap muka langsung. Untuk diketahui, pada masa pandemi COVID-19 guru mengajar dengan menggunakan sistem online (daring), dan untuk tugas guru membolehkan siswa datang ke sekolah untuk mengumpulnya.

\section{Hasil Penelitian Siklus I}

Pada siklus I, peneliti menggunakan langkah awal perencanaan, yaitu merencanakan pertemuan untuk supervisi akademik. Sebelumnya dijelaskan, bahwa untuk setiap langkah pada siklusnya, peneliti menggunakan tiap langkah untuk satu pecan, dan setiap pertemuan dilakukan pada hari Kamis selama lebih kurang 3 x 35 menit. Pada siklus I, untuk langkah perencanaan, peneliti menetapkan pertemuan pada tanggal 20 Agustus 2020, dilanjutkan dengan pelaksanaan pada hari tanggal 27 Agustus 2020, kemudian pengamatan pada tanggal 3 September 2020, dan refleksi pada tanggal 10 September 2020. Pada jangka waktu itu, sampel diberikan masukan hal-hal apa saja yang harus mereka penuhi untuk mencapai kinerja guru yang baik. Setelah semua langkah dilakukan, maka diperoleh hasil sebagai berikut:

Tabel 2. Hasil Supervisi Akademik Pad Siklus I

\begin{tabular}{llccccc}
\hline \multirow{2}{*}{ No Aspek Penilaian } & \multicolumn{5}{c}{ Kategori } \\
\cline { 3 - 7 } & & $\mathrm{S}$ & $\mathrm{B}$ & $\mathrm{C}$ & $\mathrm{K}$ & $\mathrm{T}$ \\
\hline 1 & Menguasai bahan ajar yang akan diajarkan & 2 & 10 & 3 & 3 & 2 \\
\hline 2 & Mengelola program belajar mengajar & - & 5 & 10 & 4 & 1 \\
\hline 3 & Mengelola kelas & - & 7 & 9 & 4 & - \\
\hline 4 & Menggunakan media/ sumber belajar & - & 15 & 2 & 1 & 2 \\
\hline 5 & Menguasai landasan-landasan kependidikan & - & 3 & 8 & 4 & 5 \\
\hline 6 & Mengelola interaksi belajar mengajar & 1 & 3 & 7 & 7 & 2 \\
\hline 7 & Menilai prestasi siswa & 3 & 15 & 1 & 1 & \\
\hline 8 & Mengenal fungsi dan program bimbingan dan penyuluhan & - & 12 & 3 & 1 & 4 \\
\hline 9 & Mengenal dan menyelenggarakan administrasi sekolah & - & 4 & 2 & 11 & 3 \\
\hline \multirow{2}{*}{10} & $\begin{array}{l}\text { Memahami prinsip-prinsip dan menafsirkan } \\
\text { penelitian hasil-hasil }\end{array}$ & - & - & 5 & 6 & 9 \\
\hline & Jumlah & 6 & 74 & 50 & 42 & 28 \\
\hline & Persentase (\%) & 3 & 37 & 25 & 21 & 14 \\
\hline
\end{tabular}

Dari data di atas, dapat diketahui bahwa total sampel yang memenuhi semua aspek penilaian dengan kategori minimal Baik sebanyak 80 orang, atau hanya $40 \%$ saja. Hal ini menunjukkan adanya peningkatan jumlah guru yang memenuhi aspek penilaian yang ditentukan, namun masih di bawah standar ketuntasan yang peneliti tentukan. Secara umum, sampel masih berada di kategori Baik dengan jumlah total 74 untuk semua kriteria.

Dari wawancara yang dilakukan, diperoleh hasil bahwasanya sampel berkeinginan memenuhi semua kriteria tersebut, setelah dilakukannya supervisi akademik oleh peneliti. Mereka belum benarbenar memahami apa-apa saja yang harus 
dipenuhi dari aspek-aspek penilaian tersebut. Hasil pengamatan juga menemukan bahwa sampel belum membawa semua bahan yang dapat memenuhi semua indicator kinerja guru. Oleh karena itu, peneliti mengambil kesimpulan untuk melanjutkan penelitian ini ke siklus 2

\section{Hasil penelitian siklus 2}

Langkah-langkah yang dilakukan untuk siklus 2 masih sama dengan siklus I.
Untuk perencanaan, penulis menentukan pertemuan pada tanggal 17 September 2020, pelaksanaan pada tanggal 24 September 2020, pengamatan pada tanggal 1 Oktober 2020, dan refleksi pada tanggal 8 Oktober 2020. Setelah semua langkah-langkah dilaksanakan maka diperoleh hasil seperti yang terlihat pada tabel berikut :

Tabel 3. Hasil Supervisi Akademik Pada Siklus 2

\begin{tabular}{|c|c|c|c|c|c|c|}
\hline \multirow{2}{*}{ No } & \multirow{2}{*}{ Aspek Penilaian } & \multicolumn{5}{|c|}{ Kategori } \\
\hline & & $\mathrm{S}$ & $\mathrm{B}$ & $\mathrm{C}$ & $\mathrm{K}$ & $\mathrm{T}$ \\
\hline 1 & Menguasai bahan ajar yang akan diajarkan & 10 & 10 & - & - & - \\
\hline 2 & Mengelola program belajar mengajar & 6 & 10 & 3 & 1 & - \\
\hline 3 & Mengelola kelas & 7 & 11 & 1 & 1 & - \\
\hline 4 & Menggunakan media/ sumber belajar & 6 & 12 & 1 & 1 & - \\
\hline 5 & Menguasai landasan-landasan kependidikan & 6 & 10 & 2 & 2 & - \\
\hline 6 & Mengelola interaksi belajar mengajar & 7 & 11 & 2 & - & - \\
\hline 7 & Menilai prestasi siswa & 5 & 13 & 2 & & - \\
\hline 8 & $\begin{array}{l}\text { Mengenal fungsi dan program bimbingan dan } \\
\text { penyuluhan }\end{array}$ & 4 & 11 & 2 & 1 & 2 \\
\hline 9 & Mengenal dan menyelenggarakan administrasi sekolah & 5 & 10 & 2 & 3 & - \\
\hline 10 & $\begin{array}{l}\text { Memahami prinsip-prinsip dan menafsirkan hasil-hasil } \\
\text { penelitian }\end{array}$ & 4 & 12 & 1 & 1 & 2 \\
\hline & Jumlah & 60 & 110 & 16 & 10 & 4 \\
\hline & Persentase (\%) & 30 & 55 & 8 & 5 & 2 \\
\hline
\end{tabular}

Data pada tabel di atas menunjukkan bahwa telah terjadi peningkatan kinerja guru setelah dilaksanakannya siklus 2. Jumlah sampel yang memenuhi semua aspek penilaian dengan kategori minimal baik, telah mencapai total 110, dan kategori sangat baik 60. Apabila ditambahkan, maka jumlah yang didapat adalah 170 atau sebesar $85 \%$. Hal ini menunjukkan telah terjadinya peningkatan kinerja guru yang signifikan, hingga mencapai batas yang telah ditentukan.

Hasil pengamatan juga menunjukkan bahwasanya guru telah menguasai materi dengan baik, menggunakan media dan sumber dengan baik, mengetahui fungsi dan program penyuluhan bagi siswa yang bermasalah, menguasai dan mengelola kelas dengan baik, mengelola program pengajaran dengan baik, dan lain-lain. Hasil tersebut dipertegas dengan hasil wawancara yang mana sampel mengatakan setelah dilakukannya supervise akademik secara berkelanjutan, mereka menjadi lebih mengerti hal-hal yang harus mereka penuhi dalam kaitannya dengan kinerja guru. Dikarenakan sampel penelitian telah mencapai batas minimal yang telah ditetapkan, maka penulis menyatakan bahwa penelitian ini dikatakan berhasil.

Berdasarkan hasil evaluasi supervisi akademik terhadap guru PAIBP di Kota Binjai, diperoleh terjadi peningkatan pada kinerja guru, dengan melihat aspek penilaian atau indicator yang telah ditentukan. Hal tersebut terlihat dari jumlah total sampel yang 
dapat memenuhi aspek penilaian, pada kategori baik dan sangat baik, dengan jumlah total 170 sampel atau $85 \%$. Peningkatan yang terjadi secara total adalah dengan mengurangi pencapaian total pada siklus 2 dengan siklus 1, yaitu $170-80=90$ orang sampel, dan apabila di persentasekan adalah $85 \%-40 \%=$ $45 \%$. Dengan begitu, terjadi peningkatan sebesar $40 \%$ dari non penelitian ke siklus I, dan $45 \%$ dari sikulus I ke siklus 2 .

\section{SIMPULAN}

Supervisi akademik yang dilakukan oleh pengawas terhadap kinerja guru Pendidikan Agama Islam dan Budi Pekerti di Kota Binjai, telah berhasil dengan baik. Namun begitu, diperlukan juga upaya lainnya yang bisa digunakan untuk meningkatkan kinerja guru, terutama dalam diri guru itu sendiri. Adanya kinerja yang baik bagi guru, tentunya akan dapat memajukan pendidikan di Indonesia.

\section{DAFTAR PUSTAKA}

2013, Pedoman Pelatihan

Implemantasi Kurikulum 2013, buku 1, Jakarta BPSDM dan PMP Kemendikbud

Arikunto, Suharsimi. 2010. Prosedur Penelitian Suatu Pendekatan Praktik. Jakarta: Rineka Cipta
Glickman, C.D, dkk, 2007, Supervision of Instruction: A Developmental Approach, Needham Heights, MA: Allyn Bacon

Husaini, Usman, 2006, Manajemen Teori, Praktik, dan Riset Pendidikan, Jakarta. Bumi Aksara, 2006

Maralih, 2014, Peranan Supervisi Dalam Peningkatan Kualitas Pendidikan, Jurnal Qathruna, Vol. 1 No. 1, Periode JanuariJuni

Moleong, Lexy J. 2002. Metodologi Penelitian Kualitatif. Bandung: PT Remaja Rosdakarya

Mulyasa, 2013, Pengembangan dan Implemantasi Kurikulum 2013, Bandung, P.T. Remaja Rosdakarya

Permendiknas RI Nomor 41 Tahun 2007, tentang Standar Proses untuk Satuan Pendidikan Dasar dan Menengah, Departemen Pendidikan Nasional, Jakarta

Sudjana, Nana., dkk 2004, Dasar-dasar Proses Belajar Mengajar, Bandung, Sinar Baru Algensindo

Susanati, Novi, 2019, Manajemen Supervisi Akademik Dalam Lembaga Pendidikan Islam, Al Kahfi, Jurnal Pendidikan Islam, Volume IV, No. 2, Juli

Uno, Hamzah, B., dan Nina Lamatenggo, 2014, Teori Kinerja Guru dan Pengukurannya, Jakarta, Bumi Aksara

Yamin, Martinis dan Maisah, 2010, Standarisasi Kinerja Guru, Jakarta, Persada Press. 